\title{
INTEGRASI PENDIDIKAN NILAI DALAM MEMBANGUN KARAKTER SISWA DI SEKOLAH DASAR JAMPALAN KECAMATAN SIMPANG EMPAT KABUPATEN ASAHAN PROVINSI SUMATERA UTARA Intan Kumalasari ${ }^{1}$, Luciana Nasution ${ }^{2}$, Dr. Candra Wijaya, M. Pd. ${ }^{3}$
}

intankumalasari866@gmail.com

\begin{abstract}
Value education is a system of building character values or school citizens which includes the components of knowledge, awareness or willingness, and actions to implement these values to God Almighty, oneself, others, environment, and nationality so that they become human beings who are qualified for their morals. After conducting research and interviews with several teachers, the researcher draws the conclusion that in terms of delivering value education in schools for Elementary Schools, the teacher uses a contextual learning approach model that is the effort of educators to connect the material taught with the real world situation of students, encouraging students make connections between the knowledge they have and their application in their lives as family members and communities. The learning system adopted in Jampalan Elementary School is inseparable from the existence of Asahan district Government No.19 of 2005 concerning National Education Standards and the Vision namely "Realizing a Religious, Healthy, Smart and Independent Asahan". For this reason, in relation to the regulation, every Friday some activities is held in each school. The religion program is an additional lesson whose purpose is to shape children's morals into a level of understanding of high moral values so that they can be implemented in their daily lives.
\end{abstract}

\begin{abstract}
Abstrak Pendidikan nilai adalah sistem membangun nilai-nilai karakter atau warga sekolah yang mencakup komponen pengetahuan, kesadaran atau kemauan, dan tindakan untuk menerapkan nilai-nilai ini kepada Allah SWT, diri sendiri, orang lain, lingkungan, dan kebangsaan sehingga mereka menjadi manusia yang berkualitas untuk moral mereka. Setelah melakukan penelitian dan wawancara dengan beberapa guru, peneliti menarik kesimpulan bahwa dalam hal memberikan pendidikan nilai di sekolah-sekolah untuk Sekolah Dasar, guru menggunakan model pendekatan pembelajaran kontekstual yang merupakan upaya pendidik untuk menghubungkan materi yang diajarkan dengan dunia nyata. situasi siswa, mendorong siswa membuat koneksi antara pengetahuan yang mereka miliki dan aplikasi mereka dalam kehidupan mereka sebagai anggota keluarga dan masyarakat. Sistem pembelajaran yang diterapkan di Sekolah Dasar Jampalan tidak terlepas dari keberadaan Pemerintah Kabupaten Asahan No.19 tahun 2005 tentang Standar Pendidikan Nasional dan Visi yaitu "Mewujudkan Asahan yang Religius, Sehat, Cerdas, dan Mandiri". Untuk alasan ini, sehubungan dengan peraturan tersebut, setiap hari Jumat beberapa kegiatan diadakan di setiap sekolah. Program agama adalah pelajaran tambahan yang tujuannya adalah untuk membentuk moral anak-anak menjadi tingkat pemahaman nilai-nilai moral yang tinggi sehingga mereka dapat diimplementasikan dalam kehidupan sehari-hari mereka.
\end{abstract}

\section{PENDAHULUAN}

Sekolah adalah sistem yang inti kegiatannya belajar dan mengajar. Sekolah menjadi salah satu wahana strategis membina sumber daya manusia berkualitas. Satuan pendidikan yang disebut sekolah merupakan bagian dari pendidikan yang berjenjang dan berkesinambungan. Aktivitas pengajaran adalah sebagai suatu sistem yang didalamnya terdapat berbagai sub sistem atau komponen-komponen 
yang saling mempengaruhi dalam mencapai tujuan pembelajaran. Guru/pendidik yang merancang dan melakukan kegiatan mengajar sehingga tercipta situasi yang kondusif bagi anak melakukan kegiatan pembelajaran. Syafaruddin (2006: 191)

Kandungan substansi yang tertuang dalam ketentuan pasal 1 ayat 1 UU No. 20 Tahun 2003 tentang sistem pendidikan nasional menyebutkan dengan jelas bahwa penyelenggaraan pendidikan nasional didasarkan pada orientasi dimensi nilai spiritual keagamaan, akar budaya nasional, responsif terhadap tuntutan dan tantangan perubahan zaman yang berkembang demikian cepat.(UU SISPENDIKNAS tahun 2003). Ketentuan lain yang terdapat dalam Bab II Pasal 3 menyebutkan pula bahwa Pendidikan nasional berfungsi mengembangkan kemampuan dan membentuk watak serta peradaban bangsa yang bermartabat dalam rangka mencerdaskan kehidupan bangsa, bertujuan untuk berkembangnya potensi peserta didik agar menjadi manusia yang beriman dan bertakwa kepada Tuhan Yang Maha Esa, berakhlak mulia, sehat, berilmu, cakap, kreatif, mandiri, dan menjadi warga negara yang demokratis serta bertanggung jawab.

Pendidikan dasar sebagai salah satu jenjang pendidikan dalam sistem pendidikan nasional diibaratkan sebagai tiket masuk atau "paspor" untuk melanjutkan perjalanan berikutnya. Gagalnya pendidikan pada tahap ini terutama dalam pembinaan sikap/nilai diyakini akan berdampak sistemik terhadap pendidikan berikutnya. Orientasi penyelenggaraan pendidikan dasar sangat menekankan pada pembinaan kepribadian, watak dan karakter anak. Karena itu, integrasi pendidikan yang sarat dengan nilai dan pembentukan karakter diperlukan untuk membekali peserta didik dalam mengantisipasi tantangan ke depan yang dipastikan akan semakin berat dan kompleks.

$$
\text { Waini Rasydin (2007: }
$$

mengemukakan bahwa konsep pendidikan dasar pada dasarnya ialah pendidikan nilai, di mana tujuannya ialah untuk memfasilitasi peserta didik untuk mengembangkan potensi dasar yang dimiliki dan diorientasikan untuk pembinaan dan pengembangan kepribadian, watak, dan karakter manusia seutuhnya. Sementara pembinaan aspek intelektual hanya sebagai peletak dasar saja berupa pengetahuanpengetahuan dasar dan bukan menjadi orientasi utama. Peningkatan kemampuan intelektual nantinya akan dikembangkan lebih lanjut pada jenjang pendidikan berikutnya.

Seorang guru harus memiliki syarat kepribadian dan penguasa ilmu. Guru/ pendidik akan mampu mendidik dan mengajar apabila dia mempunyai kestabilan emosi, memiliki rasa tanggung jawab yang besar untuk memajukan anak didik. Bersikap realistis, jujur serta bersikap terbuka dan peka terhadap perkembangan, terutama inovasi pendidikan. Syafaruddin (2005: 127) Guru sebagai pengembang kurikulum selanjutnya dituntut untuk mampu secara terampil menghadirkan suasana dan aktivitas pembelajaran yang 
berorientasi pada penanaman dan pembinaan kepribadian, watak dan karakter. Untuk itu pada Bab berikutnya akan dibahas bagaimana proses pendidikan nilai disekolah dilaksanakan, berkaitan dengan materi, proses pembelajaran, sistem penilaian, dan problema yang dihadapi.

Merespon hal itu, maka penulis melakukan penelitian mengenai praktik Pendidikan Nilai di Sekolah Dasar Jampalan atau lengkapnya "Sekolah Dasar Negeri Nomor 014642 Simpang Empat" terletak di Dusun IX Jampalan, Desa Simpang Empat, Kecamatan Simpang Empat, Kabupaten Asahan, provinsi Sumatera Utara.

Materi merupakan isi atau program yang diberikan kepada peserta didik dan harus berkenaan dengan tujuan pendidikan yang ingin dicapai. Materi program pendidikan pada dasarnya lebih merupakan sebaran kurikulum yang akan dilaksanakan dalam proses pendidikan.

Dalam lembaga-lembaga sekolah umumnya selalu mengedepankan pembelajaran dalam segi kognitif. Seringkali penanaman budi pekerti dan penanaman nilai dikesampingkan. Atau bahkan tidak pernah ada usaha untuk penanaman. Hanya sebagian kecil saja penanaman budi pekerti dan pendidikan nilai yang ditanamkan melalui pembelajaran di sekolah. Mungkin alasan sekolah karena mengejar target bahwa out put harus menjadi terbaik. Dan hanya memenuhi target kurikulum. Padahal penanaman budi pekerti dan pendidikan nilai adalah merupakan kunci sukses untuk menuju out put yang baik.
Pendidikan nilai di sekolah terutama pendidikan dasar dan menengah diperoleh dari semua mata pelajaran yang ada, proporsi terbesar didapat dari kelompok mata pelajaran agama dan akhlak mulia/ Budi Pekerti serta kewarganegaraan. Pendidikan sains juga menyumbang pendidikan nilai melalui pendidikan sikap ilmiah dan kerja ilmiah yang merupakan bagian metode ilmiah.

Pada hakikatnya Penanaman nilai-nilai luhur adalah melalui semua mata pelajaran, artinya pendidikan nilai tidak harus dieksplisitkan sebagai mata pelajaran khusus tetapi dapat secara implisit pada semua mata pelajaran atau bidang ilmu. Hal ini penting mengingat bahwa semua materi pelajaran baik itu yang terkait dengan ilmu eksakta seperti matematika, IPS, maupun yang terkait dengan ilmu-ilmu humaniora seperti kesusastraan dan bahasa tidak akan terlepas dengan nilai yang kaitannya dengan kehidupan manusia.

Perhatikan contoh distribusi nilai utama ke dalam semua mata pelajaran Dhanu (2011: 12):

\begin{tabular}{|c|c|}
\hline Mapel & Nilai Utama \\
\hline $\begin{array}{l}\text { Pendidikan } \\
\text { Agama }\end{array}$ & $\begin{array}{l}\text { kesantunan, kedisiplinan, } \\
\text { tanggung jawab, cinta } \\
\text { ilmu, keingintahuan, } \\
\text { percaya diri, menghargai } \\
\text { keberagaman, kepatuhan } \\
\text { terhadap aturan sosial, } \\
\text { gaya hidup sehat, } \\
\text { kesadaran akan hak dan } \\
\text { kewajiban, kerja keras }\end{array}$ \\
\hline $\mathrm{PKn}$ & $\begin{array}{l}\text { nasionalis, kepatuhan } \\
\text { terhadap aturan sosial, } \\
\text { menghargai keberagaman, } \\
\text { kesadaran akan hak dan } \\
\text { kewajiban diri dan orang }\end{array}$ \\
\hline
\end{tabular}




\begin{tabular}{|c|c|}
\hline & lain \\
\hline $\begin{array}{l}\text { Bahasa } \\
\text { Indonesia }\end{array}$ & $\begin{array}{l}\text { berpikir logis, kritis, } \\
\text { kreatif dan inovatif, } \\
\text { percaya diri, tanggung } \\
\text { jawab, keingintahuan, } \\
\text { kesantunan, nasionalis }\end{array}$ \\
\hline Matematika & $\begin{array}{l}\text { berpikir logis, kritis, kerja } \\
\text { keras, keingintahuan, } \\
\text { kemandirian, percaya diri }\end{array}$ \\
\hline IPS & $\begin{array}{l}\text { nasionalis, menghargai } \\
\text { keberagaman, berpikir } \\
\text { logis, kritis, kreatif, dan } \\
\text { inovatif, kepedulian, } \\
\text { berjiwa wirausaha, kerja } \\
\text { keras }\end{array}$ \\
\hline IPA & $\begin{array}{l}\text { keingintahuan, berpikir } \\
\text { logis, kritis, kreatif, dan } \\
\text { inovatif, gaya hidup sehat, } \\
\text { percaya diri, menghargai } \\
\text { keberagaman, } \\
\text { kedisiplinan, } \\
\text { kemandirian, tanggung } \\
\text { jawab, cinta ilmu }\end{array}$ \\
\hline $\begin{array}{l}\text { Bahasa } \\
\text { Inggris }\end{array}$ & $\begin{array}{l}\text { menghargai keberagaman, } \\
\text { kesantunan, percaya diri, } \\
\text { kemandirian, kerja sama, } \\
\text { kepatuhan terhadap aturan } \\
\text { sosial }\end{array}$ \\
\hline $\begin{array}{l}\text { Seni } \\
\text { Budaya }\end{array}$ & $\begin{array}{l}\text { menghargai keberagaman, } \\
\text { nasionalis, \& menghargai } \\
\text { karya orang lain, } \\
\text { keingintahuan, } \\
\text { kedisiplinan }\end{array}$ \\
\hline Penjaskes & $\begin{array}{l}\text { gaya hidup sehat, kerja } \\
\text { keras, kedisiplinan, } \\
\text { percaya diri, kemandirian, } \\
\text { menghargai karya dan } \\
\text { prestasi orang lain }\end{array}$ \\
\hline $\begin{array}{l}\text { TIK/Ketera } \\
\text { m-pilan }\end{array}$ & $\begin{array}{l}\text { berpikir logis, kritis, } \\
\text { kreatif, \& inovatif, } \\
\text { kemandirian, tanggung } \\
\text { jawab, dan menghargai } \\
\text { karya orang lain }\end{array}$ \\
\hline $\begin{array}{l}\text { Muatan } \\
\text { Lokal }\end{array}$ & $\begin{array}{l}\text { menghargai keberagaman, } \\
\text { menghargai karya orang } \\
\text { lain, nasionalis. }\end{array}$ \\
\hline
\end{tabular}

Sebagai bangsa yang berbudaya dan memiliki falsafah/pandangan hidup yang diyakini kebenarannya sampai saat ini, bangsa
Indonesia mulai menyadari pentingnya akhlak mulia diutamakan dalam proses pendidikan. Hal ini tercermin dalam acuan operasional penyusunan KTSP dimana acuan pertama disebutkan "peningkatan iman dan taqwa serta akhlak mulia", kemudian pada acuan kedua disebutkan "peningkatan potensi, kecerdasan, dan minat sesuai dengan tingkat perkembangan dan kemampuan peserta didik”. Jadi, bangsa kita telah menyadari hanya mereka yang memiliki iman dan taqwa serta akhlak mulia yang baik yang dapat dididik menjadi peserta didik yang mudah diarahkan dan berhasil, sehingga akan terbentuk generasi penerus bangsa yang berkarakter dan berkualitas akhlaknya sekaligus cerdas intelektualnya.Dhanu (2011: 15)

Untuk itu, para pendidik di Sekolah Dasar Jampalan mencoba menerapkan nilainilai yang terdapat pada setiap materi yang diajarkan. Hal ini tidak terlepas dari kontrol/ pengawasan Kepala Sekolah yang selalu mengingatkan para tim pengajar ketika melaksanakan supervisi sekolah yang diadakan setiap akhir bulan.

Misalnya dalam memberikan materi pada mata pelajaran Agama, guru agama diminta agar dapat mengarahkan anak didik menerima kebenaran hakikat yang diajarkan agama yang berkaitan dengan ibadah, akhlak, dan keimanan sebagai makhluk ciptaan Tuhan YME. Begitu juga pada mata pelajaran Budi Pekerti dan Kewarganegaraan. Masing-masing guru mencoba menerapkan nilai-nilai yang ada agar peserta didik dapat mengaplikasikan nilai- 
nilai yang baik dalam kehidupannya sehari-hari. Namun, hal ini bukan hanya tugas dari guru Agama, Budi Pekerti dan Kewarganegaraan, tetapi untuk semua guru agar menjadi tauladan bagi para paserta didik.

\section{METODE}

Penelitian ini merupakan studi kasus yang diarahkan untuk mendeskripsikan dan menganalisis secara mendalam tentang Intergrasi Pendidikan Nilai Dalam Membentuk Karakter di Sekolah Dasar. Oleh karena itu, pendekatan yang digunakan adalah pendekatan kualitatif. Pemilihan model ini didasarkan pada fokus penelitian yang menuntut penelitian melakukan eksplorasi untuk memahami dan menjelaskan masalah yang diteliti melalui hubungan yang intensif dengan sumber data. (Nana Syaodih Sukmadinata 2005: 64).

Teknik pengambilan informan dalam penelitian ini dilakukan secara purposive. Pengambilan informan ini dilakukan dengan cara mengambil subjek bukan didasarkan atas strata, random atau daerah tertentu, melainkan didasarkan atas adanya tujuan tertentu sesuai dengan tuntutan dan kebutuhan penelitian. Teknik dilakukan karena beberapa pertimbangan, yaitu keterbatasan waktu, tenaga, dan dana.

Dalam metode penelitian kualitatif, peneliti merupakan instrumen utama (key instrument). Hakekat peneliti sebagai instrumen kunci diaplikasikan dalam penggunaan teknik pengumpulan data. Teknik pengumpulan data dalam penelitian ini meliputi wawancara dan observasi serta penggalian dokumen (catatan atau arsip).

\section{HASIL}

Arti pendidikan nilai secara terintegrasi di dalam proses pembelajaran adalah pengenalan nilai-nilai, fasilitasi diperolehnya kesadaran akan pentingnya nilai-nilai, dan penginternalisasian nilai-nilai ke dalam tingkah laku peserta didik sehari-hari melalui proses pembelajaran, baik yang berlangsung di dalam maupun di luar kelas pada semua mata pelajaran. Dengan demikian, kegiatan pembelajaran, selain untuk menjadikan peserta didik menguasai kompetensi (materi) yang ditargetkan, juga dirancang dan dilakukan untuk menjadikan peserta didik mengenal, menyadari dan menginternalisasi nilai-nilai dan menjadikannya perilaku.

Metode adalah cara yang digunakan untuk menyampaikan materi pelajaran dalam upaya mencapaikan materi pelajaran dalam upaya mencapai tujuan instruksional yang ditetapkan. (KBBI 2005: 740) Sedangkan Strategi adalah perencanaan atau taktik yang dirancang sedemikian rupa untuk tujuan pembelajaran yang lebih khusus. Metode dan strategi merupakan suatu hal yang sangat penting dalan implementasi program pendidikan. Keduanya memuat tugas-tugas atau kegiatan yang perlu dilakukan guru ataupun para peserta didik dalam program pendidikan yang dilakukan.

Dalam kegiatan pembelajaran tidak terlepas dari berbagai variable pokok yang 
saling berkaitan, yaitu kurikulum, guru/ pendidik, pembelajaran, peserta didik. Dapat digambarkan sebagai berikut:

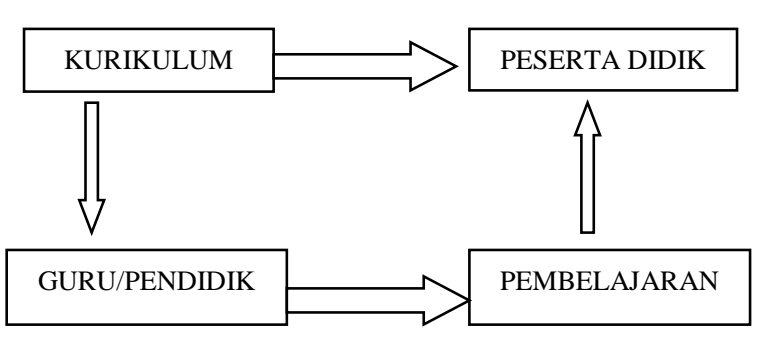

Gambar diatas menunjukkan semua komponen menuju arah untuk kepentingan peserta didik. Maka dari itu, pendidik dituntut harus mampu menggunakan berbagai model pembelajaran agar peserta didik dapat melakukan kegiatan belajar.

Setelah melakukan penelitian dan wawancara dengan beberapa guru, peneliti menarik kesimpulan bahwa dalam hal penyampaian pendidikan nilai di sekolah untuk Sekolah Dasar Jampalan para pendidik/ guru memakai model PENDEKATAN PEMBELAJARAN KONTEKSTUAL yaitu upaya pendidik untuk menghubungkan antara materi yang diajarkannya dengan situasi dunia nyata peserta didik, mendorong peserta didik melakukan hubungan antara pengetahuan yang dimilikinya dengan penerapannya dalam kehidupan mereka sebagai anggota keluarga dan masyarakat.

Seperti yang kita ketahui, pendekatan Pembelajaran Kontekstual berlangsung alamiah dalam bentuk kegiatan peserta didik bekerja dan mengalami. Dalam pendekatan ini, peserta didik dituntun untuk memahami apa itu belajar, apa manfaatnya, dalam status/ peran apa mereka, dan bagaimana mencapainya serta mengaplikasikannya dalam kehidupan nyata.

Dalam pendekatan ini, peserta didik dibiasakan untuk memecahkan masalah, menemukan sesuatu yang berguna bagi dirinya. Pendekatan Kontekstual hampir mirip dengan pendekatan perkembangan moral kognitif yakni mengasah pengetahuan siswa dengan penjelasan penalaran.

Dalam proses pembelajaran beberapa contoh penerapan penanaman nilai dapat dilihat dalam beberapa tahap, pertama tahap pendahuluan antara lain: berdoa (kereligiusan), mengecek kehadiran/absensi (kedisiplinan), menanyakan kabar peserta didik (kepedulian, empati), menyanyikan lagu Indonesia Raya (cinta tanah air), menanyakan PR (tanggung jawab), dan menanyakan piket membersihkan papan tulis (cinta kebersihan lingkungan).

Kedua, tahap kegiatan inti antara lain: diskusi (bekerja sama), mengerjakan soal ke depan (percaya diri), mendengarkan pendapat teman (menghargai pendapat), bergantian menggunakan media (tenggang rasa), bertanya (keingintahuan, kritis), mengerjakan tugas guru (kemandirian), dan melaporkan hasil diskusi (kejujuran, tanggung jawab).

Ketiga, tahap penutup antara lain: ikut menyimpulkan materi (tanggung jawab, kedisiplinan), mencatat tugas di perte-muan berikutnya (tanggung jawab, kedisiplinan, kemandirian), kesepakatan pengumpulan tugas (demokratis), berdoa (kereligiusan), keluar kelas dengan tertib (kedisiplinan), mendahulukan guru keluar kelas (kesantunan), dan 
membawa sampah keluar kelas (peduli lingkungan).

Kegiatan pembelajaran dari tahapan kegiatan pendahuluan, inti, dan penutup, dipilih dan dilaksanakan agar peserta didik mempraktikkan nilai-nilai karakter yang ditargetkan. Perilaku guru sepanjang proses pembelajaran harus merupakan model pelaksanaan nilai-nilai bagi peserta didik, artinya guru harus senantiasa dapat menjadi tauladan perilaku berkarakter bagi peserta didiknya.

Dapat disimpulkan bahwa pada dasarnya konsep pendidikan ialah pendidikan nilai, dimana tujuannya ialah untuk memfasilitasi peserta didik untuk mengembangkan potensi dasar yang dimiliki dan diorientasikan untuk pembinaan dan pengembangan kepribadian, watak, dan karakter manusia seutuhnya. Sementara pembinaan aspek intelektual hanya sebagai peletak dasar saja berupa pengetahuanpengetahuan dasar dan bukan menjadi orientasi utama. Peningkatan kemampuan intelektual nantinya akan dikembangkan lebih lanjut pada jenjang pendidikan berikutnya.

Sistem pembelajaran yang dianut di Sekolah Dasar Jampalan tidak terlepas dari adanya peraturan PEMDA No.19 Tahun 2005 tentang Standar Pendidikan Nasional dan Visi Pemerintah Kabupaten Asahan yaitu "Mewujudkan Asahan yang Religius, Sehat, Cerdas, dan Mandiri".

Menyahuti himbauan tersebut, maka setiap instansi pendidikan mengadakan kegiatan Jumat bersih. Kegiatan tersebut meliputi pemeriksaan kebersihan diri para siswa misalnya kebersihan kuku, telinga, rambut, dan sebagainya. Juga kebersihan kelas dan lingkungan sekolah yang dilaksanakan dengan cara bergotong-royong.

Ketidakseimbangan desain pendidikan yang hanya memfokuskan pada pencapaian aspek intelektual atau ranah kognitif semata dan mengambaikan aspek penanaman dan pembinaan nilai/sikap diduga sebagai penyebab munculnya degradasi atau demoralisasi terutama yang dialami oleh anak sekolah.

Untuk itu berkaitan dengan peraturan PEMDA yang disusun itu, setiap hari jumat selesai melakukan kegiatan jumat bersih di setiap sekolah diadakan PROGRAM KEAGAMAAN yakni pelajaran tambahan yang tujuannya adalah membentuk moral anak menjadi tingkat pemahaman nilai moral yang tinggi agar dapat dilaksanakan dalam kehidupannya sehari-hari. Pada kegiatan ini, sekolah mengundang nara sumber untuk masing-masing agama agar menyampaikan pesan-pesan/ khutbah yang berisikan tentang nilai-nilai kebaikan dan nilai-nilai keagamaan yang tidak terlepas dengan tata krama, sopan santun dan akhlak mulia yang oleh peserta didik nantinya akan dilaksanakan dalam hidupnya. Mereka diarahkan memiliki akhlak mulia. Jadi, tidak hanya pendidikan di Madrasah yang mendapatkan Suasana nilai moral yang lebih tinggi, tetapi untuk sekolah umum pun dapat dilaksanakan. Peraturan 
tersebut dibuat agar ada penyetaraan antara sekolah-sekolah umum dengan sekolah agama.

Untuk tingkat dasar anak mempunyai keyakinan beragama, yang diperoleh dari lingkungan rumah ataupun sekolah, misalnya anak diajarkan memikirkan Tuhan sebagai seseorang yang akan marah jika anak-anak berbuat kesalahan dan akan menghukumnya untuk dosa yang dilakukan. Di lain pihak, perayaan keagamaan di lingkungan rumah atau sekolah juga diperkenalkan pada anak, misalnya besalam-salaman untuk saling memaafkan setiap menjelang hari puasa, mengenalkan pada anak mengenai berbagai hari besar, seperti Idul Fitri, Natal, Nyepi, Waisak, juga mengenalkan berbagai tempat ibadah.

Dengan mengajarkan konsep keagamaan diajarkan dalam bahasa sehari-hari, misalnya agar anak dapat memahami tata cara makan tidak boleh sambil bicara, sebelum makan harus cuci tangan dan berdoa sebagai ungkapan rasa syukur pada Yang Maha Kuasa. Jika anak melupakannya, maka sebagai pendidik dan orang tua perlu mengingatkan kembali. Dengan mengenal konsep keagamaan, anak akan menghindari perbuatan buruk dan meningkatkan perbuatan baik.

Dan sejauh berjalannya kegiatan Jumat Keagamaan ini, terdapat perubahan karakter yang dialami peserta didik. Khususnya di sekolah dasar Jampalan. Setiap hari sebelum memulai pelajaran pertama, peserta didik berbaris teratur di depan kelas sambil menunggu instruksi masuk oleh guru yang akan mengajar, dan setiap siswa memberi hormat dan menyalam tangan guru tersebut sambil masuk satu persatu dengan tertib. Dalam hal ini, guru agama, budi pekerti dan kewarganegaraan sangat terbantu karena untuk menjalankan peraturan ini semua guru harus terlibat.

Di setiap akhir semester, sekolah dan komite mengadakan penyuluhan dengan orang tua siswa terkait dengan karakter yang dimiliki masing-masing peserta didik yang mengalami perubahan nilai moral yang baik, dan perubahan nilai yang buruk. Untuk peserta didik yang mengalami kerusakan moral dibimbing khusus dan orang tua diharapkan dapat selalu mendukung, memotivasi si anak kearah yang lebih baik. Jadi ada kerjasama yang baik antara pihak sekolah dengan orang tua.

\section{PEMBAHASAN}

\section{Sistem Penilaian}

Untuk mengetahui program itu bisa mencapai arah yang ditetapkan berkaitan erat dengan program evaluasi. Komponen evaluasi merupakan bagian yang tidak terpisahkan dalam pelaksanaan pendidikan. Hasil evaluasi dapat dipandang sebagai petunjuk apakah sasaran yang ingin dituju tercapai atau tidak, apakah ada kendala yang dialami dalam pencapaian tujuan tersebut atau tidak.

Sasaran evaluasi pada dasarnya ditujukan kepada tiga hal, antara lain:

1. Peserta didik, sampai sejauh mana siswa dapat mencapai prestasi 
belajar sesuai dengan tujuan seimbang antara hasil belajar dengan proses pendidikan.

belajar nilai. Hasil belajar selalu dikaitkan

2. Guru, sampai sejauh mana guru dengan pengetahuan yang diperoleh oleh melakukan tugasnya sebagai peserta didik terhadap materi yang pengajar dalam mengantarkan anak disampaikan guru/pendidik. Seperti yang didiknya kea rah yang ditetapkan telah dijelaskan dalam proses pembelajaran sesuai dengan tujuan pendidikan.

3. Program, sampai sejauh mana program yang telah disiapkan cukup andal dan relevan guna mencapai tujuan pendidikan. Dinn Wahyudin (2005: 35) sebelumnya, sasaran proses pembelajaran dilakukan dari kegiatan pendahuluan, inti dan penutup. Apabila ketiga tahapan ini sering dilaksanakan, maka pendidikan nilai di sekolah akan terlaksana dengan baik.

\section{Problema Yang Dihadapi}

Melalui kajian evaluasi yang ada, Pelaksanaan pendidikan nilai secara akan diperoleh beberapa masukan berdasarkan umpan balik yang ada. Oleh karena itu ada dua sasaran utama pokok evaluasi dalam kaitannya dengan pelaksanaan pendidikan, yaitu:

1. Evaluasi terhadap hasil, artinya evaluasi ini menilai sampai sejauh mana keberhasilan garapan pendidikan telah dilaksanakan guna mengantarkan peserta didik dalam pencapaian tujuan pendidikan.

2. Evaluasi terhadap proses, artinya kegiatan evaluasi yang menitikberatkan kepada penilaian apakah proses pelaksanaan pendidikan ini efektif atau tidak. Dinn Wahyudin (2005)

Dari dua sasaran diatas dalam terpadu di dalam semua mata pelajaran merupakan hal yang baru bagi sebagian besar sekolah, baik di tingkat SD, SMP, maupun SMA. Oleh karena itu, dalam rangka membina pelaksanaan pendidikan karakter secara terpadu di dalam seluruh mata pelajaran, perlu disusun panduan pelaksanaan pendidikan karakter yang terintegrasi ke dalam pembelajaran.

Sebenarnya selama ini tanpa disadari semua guru SD khususnya telah menanamkan nilai-nilai yang baik dalam pembentukan karakter peserta didiknya. Namun hal itu hanya sebagai sisipan yang tidak termuat dalam silabus maupun RPP. Oleh karena itu perlu adanya optimalisasi pendidikan karakter dalam pembelajaran, pendidikan nilai di sekolah haruslah 
pembelajaran dapat benar-benar dirasakan peserta didik.

Kendala atau problem yang sering dihadapi adalah tidak adanya kesinambungan kerjasama antara guru dan orang tua. Pendidikan nilai yang diajarkan di sekolah haruslah mendapat dukungan oleh orang tua. Tidak hanya itu, bagi sekolah-sekolah yang terisolir, jarang mereka mendapatkan info terkini tentang pendidikan nilai yang sedang digalakkan mengingat fasilitas yang kurang memadai. Hal ini juga dipacu oleh pendidikan guru yang terbatas.

Pada Sekolah Dasar Jampalan problem yang sering muncul ketika diadakan rapat dengan orang tua peserta didik, hanya sedikit atau sekitar $60 \%$ saja yang hadir. Maka hanya orang tua yang hadirlah yang mengetahui apa yang harus dilakukan mereka dalam mendidik peserta didik ketika berada di lingkungan keluarga. Sehingga adanya peserta didik yang masih melenceng moralnya hal itu dikarenakan tidak adanya kesinambungan kerjasama antara pihak sekolah dengan orang tua.

Selain itu, pada program keagamaan sekolah sering kesulitan mencari nara sumber dari pihak luar untuk menyampaikan nilai-nilai keagamaan dan akhlak mulia. Hal ini disebabkan terbenturnya dana operasional untuk hal tersebut. Ketika diminta kerjasama dengan peserta didik untuk mengumpulkan sedikit uang jajan mereka, banyak orang tua yang mengeluh. Mereka beralasan tidak ada pungutan biaya untuk Sekolah Dasar dikarenakan adanya dana BOS. Untuk itu, kepala sekolah mengambil kebijakan agar setiap guru, mempersiapkan materi keagamaan sesuai dengan agama masingmasing sebagai pengganti nara sumber tersebut. Maka sebagai tauladan bagi peserta didik, guru/ pendidik harus siap dan menggunakan metode-metode yang bervariasi agar peserta didik tidak merasa jenuh/ bosan.

Pendidikan nilai adalah suatu sistem penanaman nilai-nilai karakter kepada warga sekolah yang meliputi komponen pengetahuan, kesadaran atau kemauan, dan tindakan untuk melaksanakan nilai-nilai tersebut, baik terhadap Tuhan Yang Maha Esa (YME), diri sendiri, sesama, lingkungan, maupun kebangsaan sehingga menjadi manusia yang berkualiatas akhlaknya.

Untuk itu, dalam pendidikan nilai di sekolah, semua komponen (stakeholders) harus dilibatkan, termasuk komponenkomponen pendidikan itu sendiri, yaitu isi kurikulum, proses pembelajaran dan penilaian, kualitas hubungan, penanganan atau pengelolaan mata pelajaran, 
pengelolaan sekolah, pelaksanaan aktivitas atau kegiatan ko-kurikuler, pemberdayaan sarana prasarana, pembiayaan, dan etos kerja seluruh warga dan lingkungan sekolah.

\section{SIMPULAN}

Pendidikan nilai adalah suatu sistem penanaman nilai-nilai karakter kepada warga sekolah yang meliputi komponen pengetahuan, kesadaran atau kemauan, dan tindakan untuk melaksanakan nilai-nilai tersebut, baik terhadap Tuhan Yang Maha Esa (YME), diri sendiri, sesama, lingkungan, maupun kebangsaan sehingga menjadi manusia yang berkualiatas akhlaknya. Setelah melakukan penelitian dan wawancara dengan beberapa guru, peneliti menarik kesimpulan bahwa dalam hal penyampaian pendidikan nilai di sekolah untuk Sekolah Dasar Jampalan para pendidik/ guru memakai model pendekatan pembelajaran kontekstual yaitu upaya pendidik untuk menghubungkan antara materi yang diajarkannya dengan situasi dunia nyata peserta didik, mendorong peserta didik melakukan hubungan antara pengetahuan yang dimilikinya dengan penerapannya dalam kehidupan mereka sebagai anggota keluarga dan masyarakat.

Sistem pembelajaran yang dianut di Sekolah Dasar Jampalan tidak terlepas dari adanya peraturan pemerintah daerah No.19
Tahun 2005 tentang Standar Pendidikan Nasional dan Visi Pemerintah Kabupaten Asahan yaitu "Mewujudkan Asahan yang Religius, Sehat, Cerdas, dan Mandiri". Untuk itu berkaitan dengan peraturan itu, setiap hari jumat selesai melakukan kegiatan jumat bersih di setiap sekolah diadakan PROGRAM KEAGAMAAN yakni pelajaran tambahan yang tujuannya adalah membentuk moral anak menjadi tingkat pemahaman nilai moral yang tinggi agar dapat dilaksanakan dalam kehidupannya sehari-hari.

\section{DAFTAR RUJUKAN}

Dinn Wahyudin. (2007). Pengantar Pendidikan. Jakarta: Universits Terbuka.

Dhanu. (2011). Pola Pendidikan Nilai di Sekolah . Bandung: Cita pustaka media.

Kamus Besar Bahasa Indonesia. (2005). edisi ke 3. Jakarta: Balai Pustaka.

Rasyidin, Waini. (2007). Landasan Filosofis Pendidikan Dasar. Bandung: SPs UPI.

Syafaruddin. (2005). Ilmu Pendidikan. Bandung: Citapustaka Media. .(2006). Ilmu Pendidikan Islam.

Jakarta: Hijri Pustaka Utama.

Sukmadinata, Nana Syaodih.(2005). Metode Penelitian Pendidikan. Bandung: PT Remaja Rosdakarya,

Undang-undang Nomor 20 Tahun 2003 tentang Sistem Pendidikan Nasional 